\title{
Influence of Rainfall on the Physicochemical Characteristics of a Tropical River in Sarawak, Malaysia
}

\author{
Teck-Yee Ling ${ }^{1 *}$, Chen-Lin Soo ${ }^{1}$, Jing-Jing Liew ${ }^{1}$, Lee Nyanti², \\ Siong-Fong Sim ${ }^{1}$, Jongkar Grinang ${ }^{3}$ \\ ${ }^{1}$ Department of Chemistry, Faculty of Resource Science and Technology, Universiti Malaysia Sarawak, \\ 94300 Kota Samarahan, Sarawak, Malaysia \\ ${ }^{2}$ Department of Aquatic Science, Faculty of Resource Science and Technology, Universiti Malaysia Sarawak, \\ 94300 Kota Samarahan, Sarawak, Malaysia \\ ${ }^{3}$ Institute of Biodiversity and Environmental Conservation, Universiti Malaysia Sarawak, \\ 94300 Kota Samarahan, Sarawak, Malaysia
}

Received: 28 November 2016

Accepted: 12 March 2017

\begin{abstract}
A rainfall event is an important factor that can greatly affect the water quality of a river, particularly in a tropical country where the seasonal variations of river water quality are mainly dominated by precipitation. Hence, the present study aimed to determine the changes in the physicochemical characteristics of the Batang Baram, a tropical river in Malaysia, due to a rainfall event. Two samplings were conducted in the Baram in Sarawak before and after rain. The results show that the mean velocity and mean depth of the river increased substantially after rain. The high volume of surface runoff coupled with the fast-flowing river significantly increased the dissolved oxygen, oxygen saturation, turbidity, chlorophyll $a$, total sulphide, hydrogen sulphide, and nitrite-nitrogen in the river after rain; whereas the $\mathrm{pH}$, transparency, and organic nitrogen decreased significantly after rain. The water quality index (WQI) in the tributary after rain showed improvement mainly due to an increase in the concentration of dissolved oxygen. On the other hand, the total suspended solids in the main river after rain changed from Class I/II/III to Class III/V due to soil erosion.
\end{abstract}

Keywords: physicochemical parameters of surface waters, water quality index, Baram River, Borneo Island

\section{Introduction}

In recent years, extreme rainfall events and an increase in rainfall variability have been reported in different parts

*e-mail: tyling@unimas.my of the world as a result of climate change [1-2]. Such changes in rainfall have a direct impact on water bodies. The rainfall-induced risks on the quality of the water bodies are of more concern in a tropical country where seasonality is primarily governed by precipitation [3]. A rainfall event can greatly affect the physicochemical characteristics of a water body by changing its hydrological conditions, bringing substantial amounts of pollutants 
via rainfall runoff [3-7]. These can cause water pollution and eutrophication and subsequently endanger the living organisms in the water body [8-11].

The Batang Baram ("batang" denotes big river; coordinates: $4^{\circ} 35^{\prime} 5.28^{\prime \prime} \mathrm{N}$ and $113^{\circ} 58^{\prime} 44.256^{\prime \prime} \mathrm{E}$ ) is the third longest river in Malaysia. It is located on the northern part of Sarawak, where its mouth is approximately $29 \mathrm{~km}$ north of the city of Miri. It has been an important source of fisheries products and a major source for drinking water for rural communities. As logging and timber extraction have been carried out in the Upper Baram area [12] and agricultural developments are increasingly important in the watershed, the river water can be seriously impacted by a rainfall event that potentially threatens aquatic organisms and public health.

Hence, the aim of the present study was to investigate the changes in the physicochemical characteristics of the Batang Baram due to a rainfall event. The investigation of the changes due to the effects of rainfall runoff on the river is highly necessary for watershed management. Besides, the impacts of rainfall runoff on river water can be intensified through interactions with different land use such as forestry, agriculture, and residential development in the adjacent area [13-15]. Hence, the impact of land use such as longhouses and logging activities near the river on its water quality is also described in the present study.

\section{Materials and Methods}

\section{Study Area}

Ten sampling stations were selected along the Batang Baram and its tributaries covering a distance of $32 \mathrm{~km}$ (Fig. 1). Five stations were located at the main river of Baram while five stations were located at tributaries, namely Patah, Piping, Jertang, Kesseh, and Nakan. Land use activities near each of the sampling stations are included in Table 1.

\section{Field Study}

Two sampling trips were carried out where no rain was recorded for a week prior to the first sampling, while it rained one night before the second sampling. Details of the two samplings carried out in January and March 2016 are included in Table 1. In situ parameters including temperature, dissolved oxygen (DO), oxygen saturation (DOsat), $\mathrm{pH}$, conductivity, and turbidity were measured using a multiparamater water quality sonde (YSI6920 V2-2). Transparency, depth, and flow velocity were measured using a secchi disc with a measuring tape, a depth sounder (PS-7, Hondex), and a stream flow meter (Geopacks), respectively. All in situ parameters were measured in triplicate except for flow velocity. Mean velocity and mean depth were calculated according to [16]. Water samples were taken for the analyses of chlorophyll $a$ (chl $a$ ), total suspended solids (TSS), fiveday biochemical oxygen demand $\left(\mathrm{BOD}_{5}\right)$, chemical oxygen demand (COD), total sulphide (TS), total ammonia nitrogen (TAN), nitrite-nitrogen $\left(\mathrm{NO}_{2}^{-}-\mathrm{N}\right)$, nitrate-nitrogen $\left(\mathrm{NO}_{3}^{-}-\mathrm{N}\right)$, organic nitrogen (Org-N), and total phosphorus (TP). All sampling bottles were acid-washed, cleaned, and dried before use. Analyses of chl $a$, TSS, $\mathrm{BOD}_{5}, \mathrm{NO}_{2}^{-}-\mathrm{N}$, $\mathrm{NO}_{3}^{-}-\mathrm{N}$, and TS were conducted in the field immediately after sampling. Water samples were acidified to $\mathrm{pH}<2$ for COD, TP, TAN, and Org-N analyses. The samples were placed in an ice box and transported to the laboratory for further analysis [17].

\section{Laboratory Analyses}

All the analyses were conducted in triplicate according to the standard methods [17-18]. Chl $a$ was determined

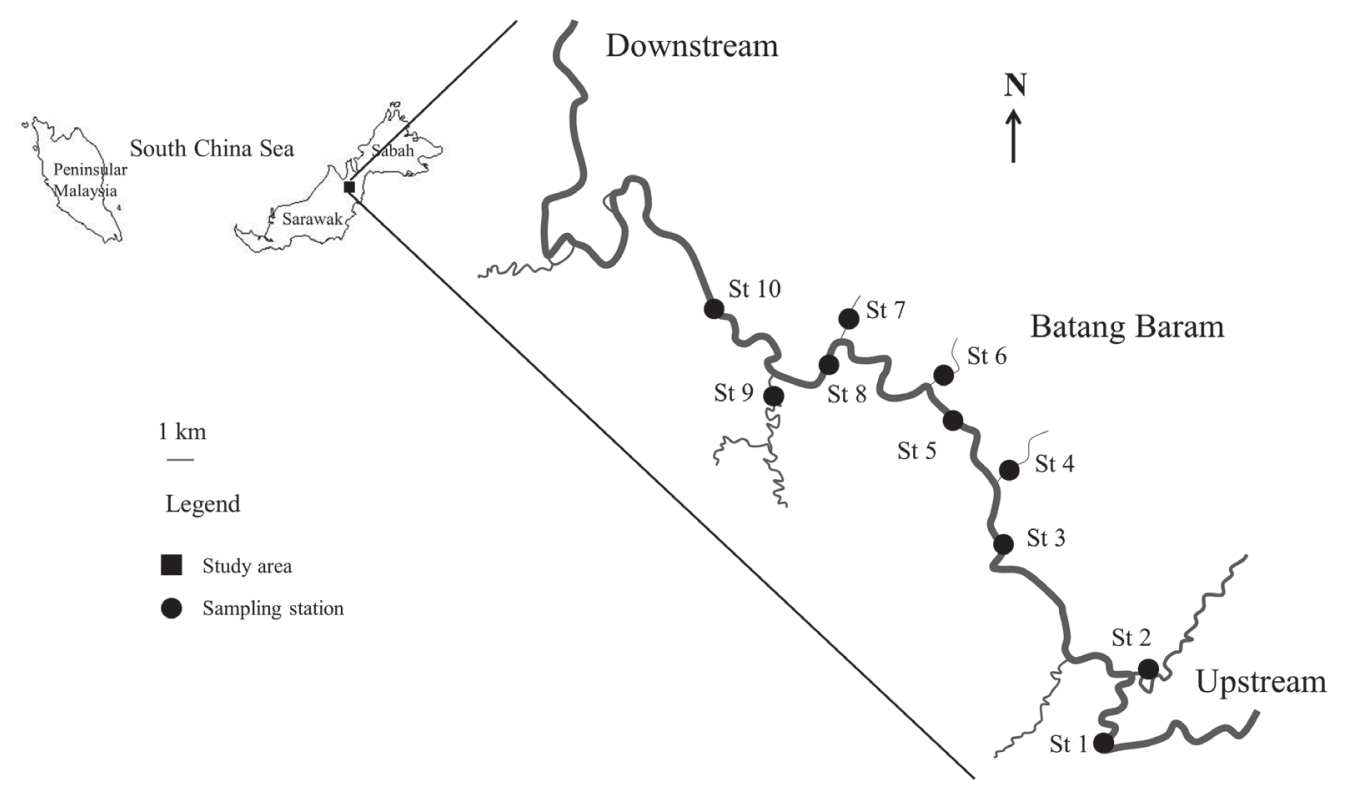

Fig. 1. The study area and location of the sampling stations. 
from samples filtered through a $0.7 \mu \mathrm{m}$ glass microfibre filter (Whatman GF/F) and extracted for $24 \mathrm{~h}$ using 90\% $(\mathrm{v} / \mathrm{v})$ acetone. TSS was calculated as the difference between the initial and final weight of the $1.0 \mu \mathrm{m}$ glass microfibre filter (Whatman GF/B), after filtration of an adequate sample volume and drying to constant weight at $105^{\circ} \mathrm{C}$. $\mathrm{BOD}_{5}$ was determined as the difference between the initial and final DO content, after a five-day long incubation of the sample. For the initial DO content, it was measured in the field whereby it was raised by vigorous aeration if the in situ DO value was too low. COD was determined by the closed reflux method followed by the titrimetric method. TP was determined by the ascorbic acid method after persulfate digestion of samples. TAN, $\mathrm{NO}_{2}^{-}-\mathrm{N}$, and $\mathrm{NO}_{3}^{-}-\mathrm{N}$ were determined by Nessler's method, the diazotization method (low range), and the cadmium reduction method, respectively. Water samples were filtered through a $0.7 \mu \mathrm{m}$ glass microfibre filter (Whatman $\mathrm{GF} / \mathrm{F}$ ) prior to the analyses of $\mathrm{NO}_{2}^{-}-\mathrm{N}^{-}$and $\mathrm{NO}_{3}^{-}-\mathrm{N}$. Org-N was determined by the Macro-Kjeldahl Method where ammonia was removed from the water sample before digestion and distillation, followed by Nessler's method. TS was analyzed using the methylene blue method. $\mathrm{H}_{2} \mathrm{~S}$ was calculated according to [17] with the following equation:

$$
H_{2} S=\frac{T S}{10^{p H-p K^{\prime}}+1}
$$

... where $\mathrm{H}_{2} \mathrm{~S}$ is the unionized hydrogen sulphide, TS is the total sulphide, and $\mathrm{pK}^{\prime}$ is the conditional first dissociation constant of hydrogen sulphide for freshwater.
A calibration curve was constructed for each chemical analysis. Blank and standard solutions were treated in the same way as the sample.

\section{Water Quality Index (WQI)}

Water quality index (WQI), which combines the six variables of $\mathrm{DO}, \mathrm{BOD}, \mathrm{COD}$, TSS, $\mathrm{AN}$, and $\mathrm{pH}$, was calculated with the following equation:

$$
\begin{gathered}
W Q I=0.22 \times S I_{D O}+0.19 \times S I_{B O D}+0.16 \times \\
\times S I_{C O D}+0.15 \times S I_{A N}+0.16 \times S I_{S S}+ \\
+0.12 \times S I_{p H}
\end{gathered}
$$

...where $\mathrm{SI}_{\mathrm{DO}}$ is the subindex for $\mathrm{DO}$ (\% saturation), $\mathrm{SI}_{\mathrm{BOD}}$ is the subindex for BOD $(\mathrm{mg} / \mathrm{L}), \mathrm{SI}_{\mathrm{COD}}$ is the subindex for $\mathrm{COD}(\mathrm{mg} / \mathrm{L}), \mathrm{SI}_{\mathrm{AN}}$ is the subindex for $\mathrm{AN}(\mathrm{mg} / \mathrm{L}), \mathrm{SI}_{\mathrm{SS}}$ is the subindex for $\mathrm{SS}(\mathrm{mg} / \mathrm{L})$, and $\mathrm{SI}_{\mathrm{pH}}$ is the subindex for $\mathrm{pH}[19]$.

\section{Statistical Analyses}

Comparison of water quality parameters between the stations in the Batang Baram was conducted using oneway ANOVA and Tukey's pairwise comparisons with $5 \%$ significance level. The Student's $t$-test was used to compare the water quality between the main river and tributary stations. A positive value of mean difference indicated that the parameter studied was higher in the main

\begin{tabular}{|c|c|c|c|}
\hline Station & Trip 1 & Trip 2 & Remark \\
\hline $\begin{array}{c}\text { Station 1: Batang Baram } \\
\text { N03 }^{\circ} 19^{\prime} 50.8^{\prime \prime} \text { E114 } 35^{\prime} 43.1^{\prime \prime}\end{array}$ & $13 / 01 / 16$ & $14 / 03 / 16$ & $\begin{array}{l}\text { Near the Long Na'ah longhouse } \\
\text { Presence of logging activities }\end{array}$ \\
\hline 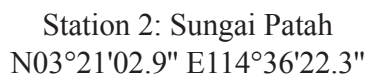 & $13 / 01 / 16$ & $14 / 03 / 16$ & Presence of logging activities \\
\hline 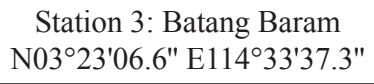 & $13 / 01 / 16$ & $14 / 03 / 16$ & Presence of logging activities \\
\hline $\begin{array}{c}\text { Station 4: Sungai Piping } \\
\text { N03}^{\circ} 24^{\prime} 47.4^{\prime \prime} \text { E114 } 14^{\circ} 29.0^{\prime \prime}\end{array}$ & $13 / 01 / 16$ & $14 / 03 / 16$ & Presence of logging activities \\
\hline 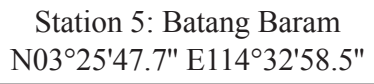 & $13 / 01 / 16$ & $14 / 03 / 16$ & Presence of logging activities \\
\hline $\begin{array}{c}\text { Station 6: Sungai Jertang } \\
\text { N03 }^{\circ} 26^{\prime} 19.3^{\prime \prime} \text { E114²32'28.3" }\end{array}$ & $13 / 01 / 16$ & $13 / 03 / 16$ & Presence of logging activities \\
\hline 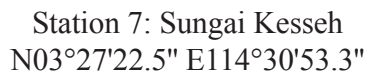 & $14 / 01 / 16$ & $13 / 03 / 16$ & $\begin{array}{l}\text { Near the Long Kesseh longhouse } \\
\text { Presence of logging activities }\end{array}$ \\
\hline 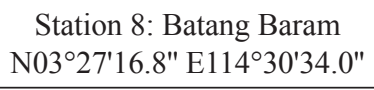 & $14 / 01 / 16$ & $13 / 03 / 16$ & $\begin{array}{l}\text { Near the Long Kesseh longhouse } \\
\text { Presence of logging activities }\end{array}$ \\
\hline $\begin{array}{c}\text { Station 9: Sungai Nakan } \\
\text { N03²26'29.6" E114²9'20.6" }\end{array}$ & $14 / 01 / 16$ & $13 / 03 / 16$ & $\begin{array}{l}\text { Near the Long Nakan longhouse } \\
\text { Presence of oil palm plantation } \\
\text { Presence of logging activities }\end{array}$ \\
\hline $\begin{array}{l}\text { Station 10: Batang Baram } \\
\text { N03}^{\circ} 6^{\prime} 24.7^{\prime \prime} \text { E114 } 32^{\prime} 08.2^{\prime \prime}\end{array}$ & $14 / 01 / 16$ & $13 / 03 / 16$ & Presence of logging activities \\
\hline
\end{tabular}
river of Batang Baram, whereas a negative value indicates that the parameter studied was higher in the tributary.

Table 1. Details of the sampling regime and sampling stations surveyed in the present study. 
The influence of rain on the water quality of the river was determined by comparing the first and second trips using Student's $t$-test. A positive value of mean difference indicated that the parameter studied increased after rain, whereas a negative value indicates a decrease after rain. Pearson's correlation analysis was performed to determine the relationship among all the parameters during each trip. Cluster analysis was used to investigate the grouping of the sampling stations by using the water quality parameters collected in the river. Z-score standardization of the variables and Ward's method using Euclidean distances as a measure of similarity were used. All the statistical analyses were carried out using the Statistical Software for Social Sciences (SPSS Version 22, SPSS Inc. 1995).

\section{Results and Discussion}

Physicochemical Characteristics of the Batang Baram and its Tributaries before and after Rain

The present study shows that rainfall has a great impact on the in situ parameters of the Batang Baram and its tributaries (Fig. 2). Mean velocity and mean depth of the river were found higher after rain, although it was not significantly different ( $p$ value $>0.05$ ), as shown in Table 2. The mean flow velocity of the Batang Baram and its tributaries ranged from $0.09 \mathrm{~m} / \mathrm{s}$ to $0.89 \mathrm{~m} / \mathrm{s}$ and from $0.06 \mathrm{~m} / \mathrm{s}$ to $1.79 \mathrm{~m} / \mathrm{s}$ before and after the rainfall event, respectively. The highest mean velocity was
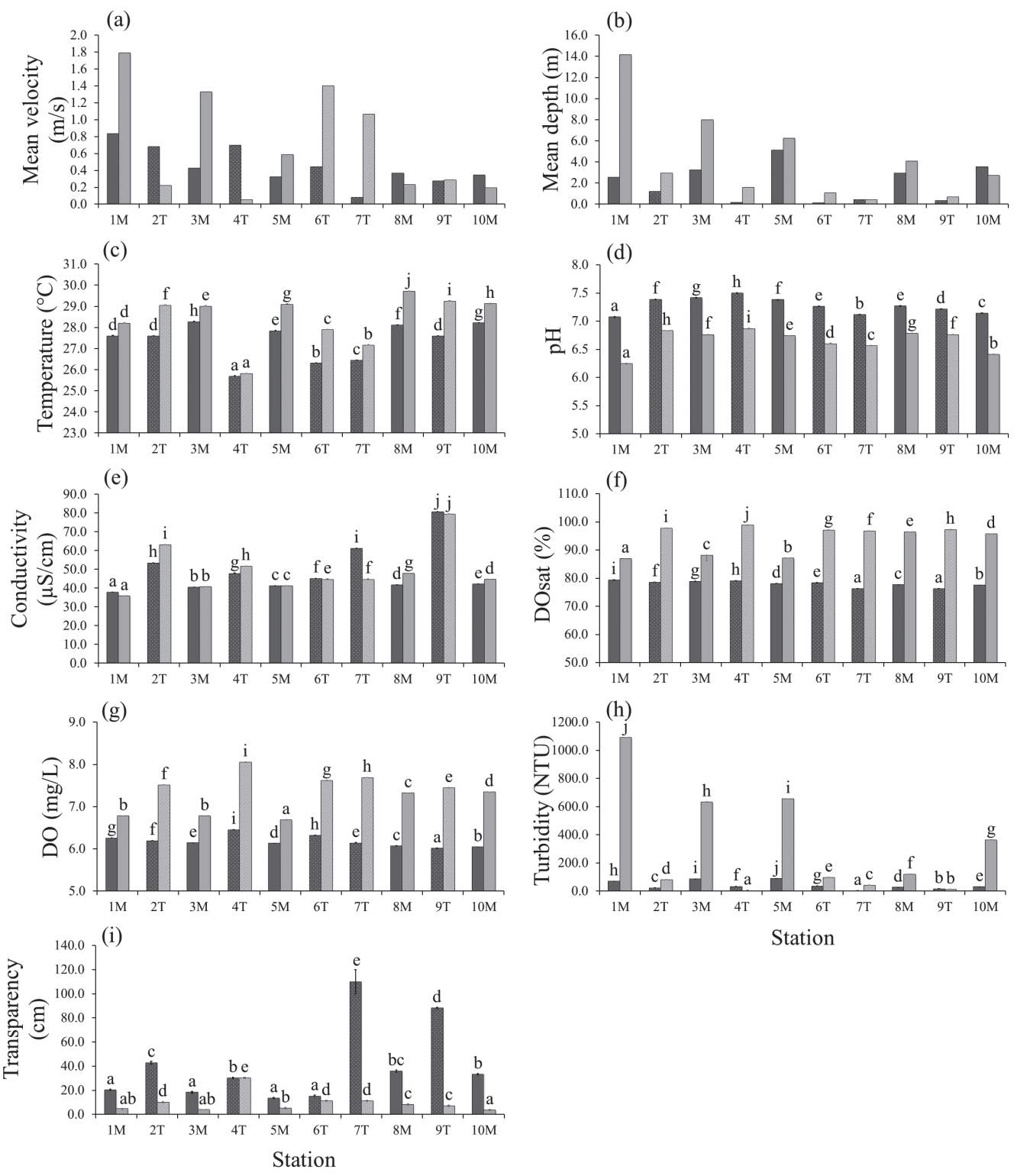

Station

Legend $\square$ Trip $1 \quad \square$ Trip 2

Fig. 2. In situ parameters of a) mean velocity, b), mean depth, c) temperature, d) pH, e) conductivity, f) DOsat, g) DO, h) turbidity, and i) transparency collected at the ten sampling stations located along the Batang Baram during two different trips (different letters indicate significant difference at $p$ value $\leq 0.05$ during each trip). 
Table 2. Mean difference of in situ and ex situ water quality parameters between the first trip (no rain recorded for a week before sampling) and second trip (rained one night before sampling).

\begin{tabular}{|c|c|c|c|}
\hline \multicolumn{2}{|r|}{ Parameters } & Mean Difference & $p$ value \\
\hline \multirow{9}{*}{ In situ } & Mean velocity, $\mathrm{m} / \mathrm{s}$ & +0.3 & 0.083 \\
\hline & Mean depth, m & +2.2 & 0.216 \\
\hline & Temperature, ${ }^{\circ} \mathrm{C}$ & +1.1 & 0.000 \\
\hline & $\mathrm{pH}$ & -0.6 & 0.000 \\
\hline & $\begin{array}{c}\text { Conductivity, } \mu \mathrm{S} / \\
\mathrm{cm}\end{array}$ & +0.2 & 0.926 \\
\hline & DOsat, \% & +16.2 & 0.000 \\
\hline & $\mathrm{DO}, \mathrm{mg} / \mathrm{L}$ & +1.1 & 0.000 \\
\hline & Turbidity, NTU & +268.8 & 0.036 \\
\hline & Transparency, cm & -31.2 & 0.015 \\
\hline \multirow{11}{*}{ Ex situ } & $\mathrm{Chl} a, \mathrm{mg} / \mathrm{m}^{3}$ & +1.8 & 0.028 \\
\hline & $\mathrm{TSS}, \mathrm{mg} / \mathrm{L}$ & +322.5 & 0.057 \\
\hline & $\mathrm{BOD}_{5}, \mathrm{mg} / \mathrm{L}$ & -1.0 & 0.053 \\
\hline & $\mathrm{COD}, \mathrm{mg} / \mathrm{L}$ & -1.1 & 0.940 \\
\hline & $\mathrm{TS}, \mathrm{mg} / \mathrm{L}$ & +0.46 & 0.018 \\
\hline & $\mathrm{H}_{2} \mathrm{~S}, \mathrm{mg} / \mathrm{L}$ & +0.37 & 0.019 \\
\hline & TAN, mg/L & -0.12 & 0.093 \\
\hline & $\mathrm{NO}_{2}{ }^{-}-\mathrm{N}, \mathrm{mg} / \mathrm{L}$ & +0.005 & 0.008 \\
\hline & $\mathrm{NO}_{3}{ }^{-}-\mathrm{N}, \mathrm{mg} / \mathrm{L}$ & +0.007 & 0.522 \\
\hline & Org-N, mg/L & -0.31 & 0.000 \\
\hline & $\mathrm{TP}, \mathrm{mg} / \mathrm{L}$ & -0.17 & 0.474 \\
\hline
\end{tabular}

The significant difference at $p$ value $\leq 0.05$ is indicated in bold.

observed at station 1 and it showed a decreasing trend as we move downstream along the main river during both sampling trips. The mean velocity in tributaries also showed a decreasing trend from the upper part of the river to downstream before rain, but higher mean velocity was observed at stations 6 and 7 after rain. The mean depth of the river increased from $2.0 \mathrm{~m}$ to $4.2 \mathrm{~m}$ after rain and it shows a decreasing trend along the main river and tributaries after rain. There was no significant difference in mean velocity between the main river and tributaries ( $p$ value $>0.05$ ), but the main river was significantly deeper than tributaries both before and after rain ( $p$ value $\leq 0.05$ ).

River temperature of the Batang Baram ranged from $25.7^{\circ} \mathrm{C}$ to $28.3^{\circ} \mathrm{C}$ and from $25.8^{\circ} \mathrm{C}$ to $29.3^{\circ} \mathrm{C}$ during the first and second trips, respectively. The river temperature was significantly higher $(p$ value $\leq 0.05)$ during the second trip, although it rained one night before the sampling. The results indicated that the rainfall event at the previous night did not have a major influence on the river temperature in the present study. River temperature was found to be significantly lower ( $p$ value $\leq 0.05$ ) in the tributaries as they were more shady than the main river. This indicates that direct solar radiation might have more influence on river temperature than the rainfall event. Besides, the river temperature was significantly and positively correlated $(p$ value $\leq 0.05$ ) with mean velocity of the river before rain (Table 4), and significantly and negatively correlated ( $p$ value $\leq 0.05$ ) with transparency after rain (Table 5), showing that the elevated suspended solids in the Batang Baram had increased the river water temperature [20].

There was no sign of acidification of the river water as shown by the $\mathrm{pH}$ value of more than 7 during the first trip. However, significantly lower $\mathrm{pH}$ values were observed at stations 1 and 10 in the main river during both trips ( $p$ value $\leq 0.05$ ), which were most likely attributed to the domestic discharge from the adjacent longhouse and residential area [21-23]. In addition, the $\mathrm{pH}$ values decreased from 7.1 to 6.3 at the two stations after rain. $\mathrm{pH}$ values of the Batang Baram and its tributaries were significantly lower $(p$ value $\leq 0.05)$ after rain than before rain (Table 2). After the rainfall event, the mean velocity was significantly and positively correlated ( $p$ value $\leq 0.05$ ) with $\mathrm{BOD}_{5}, \mathrm{TS}$, and $\mathrm{H}_{2} \mathrm{~S}$. The relationships indicate that the increased surface runoff after rain had brought in more organic matter into the river, hence the decrease of the $\mathrm{pH}$ value in the river. The conductivity value in the main river increased downstream with the lowest conductivity value being observed at station $1(\approx 36.9 \mu \mathrm{S} / \mathrm{cm})$ during both trips and the highest value at station $10(42.3 \mu \mathrm{S} / \mathrm{cm})$ and station $8(48.0 \mu \mathrm{S} / \mathrm{cm})$ during the first and second trips, respectively. Significantly higher ( $p$ value $\leq 0.05$ ) conductivity value was observed at station 9 in a tributary. Conductivity of tributaries was significantly higher $(p$ value $\leq 0.05)$ than the main river before rain (Table 3 ).

The Batang Baram and its tributaries were well oxygenated with a mean DO value of more than $5 \mathrm{mg} / \mathrm{L}$ at all stations. Before rain, the DOsat and DO values showed a decreasing trend toward downstream in the main river. However, significantly higher DOsat and DO values ( $p$ value $\leq 0.05$ ) were observed downstream of the main river after rain. The mean values of DO and DOsat of the river were significantly higher $(p$ value $\leq 0.05)$ after rain, whereby it increased from $6.2 \mathrm{mg} / \mathrm{L}$ to $7.3 \mathrm{mg} / \mathrm{L}$ and from $78.1 \%$ to $94.3 \%$. It was also observed that the rainfall has more influence on the tributaries than the main river, where the DO and DOsat values were significantly higher $(p$ value $\leq 0.05)$ in tributaries after rain with a mean value of $7.7 \mathrm{mg} / \mathrm{L}$ and $97.6 \%$, respectively. The DO value was found significantly and negatively correlated with temperature ( $p$ value $\leq 0.05$ ) before rain, as cooler water holds more oxygen. After the rainfall event, the DOsat and DO values were significantly and negatively correlated with mean velocity ( $p$ value $\leq 0.05$ ). Besides, the DOsat and DO values were significantly and negatively correlated with turbidity, TSS, COD, TS, and $\mathrm{H}_{2} \mathrm{~S}$ ( $p$ value $\leq 0.05$ ), while the DOsat value was significantly and negatively correlated with $\mathrm{BOD}_{5}(p$ value $\leq 0.05)$. 
Table 3. Mean difference of in situ and ex situ water quality parameters between the main river of the Batang Baram and its tributaries during the first trip (no rain recorded for a week before sampling) and second trip (rained one night before sampling).

\begin{tabular}{|c|c|c|c|c|c|}
\hline \multirow{2}{*}{\multicolumn{2}{|c|}{ Parameters }} & \multicolumn{2}{|c|}{ Before rain } & \multicolumn{2}{|c|}{ After rain } \\
\hline & & \multirow{2}{*}{$\begin{array}{c}\text { Mean Difference } \\
+0.0\end{array}$} & \multirow{2}{*}{$\frac{p \text { value }}{0.888}$} & \multirow{2}{*}{$\frac{\text { Mean Difference }}{+0.2}$} & \multirow{2}{*}{$\frac{p \text { value }}{0.607}$} \\
\hline \multirow{9}{*}{ In situ } & Mean velocity, m/s & & & & \\
\hline & Mean depth, $m$ & +3.0 & 0.000 & +5.7 & 0.023 \\
\hline & Temperature, ${ }^{\circ} \mathrm{C}$ & +1.3 & 0.012 & +1.2 & 0.116 \\
\hline & $\mathrm{pH}$ & +0.0 & 0.678 & -0.1 & 0.308 \\
\hline & Conductivity, $\mu \mathrm{S} / \mathrm{cm}$ & -17.0 & 0.029 & -14.8 & 0.065 \\
\hline & DOsat, \% & +0.6 & 0.431 & -6.7 & 0.015 \\
\hline & $\mathrm{DO}, \mathrm{mg} / \mathrm{L}$ & -0.1 & 0.265 & -0.7 & 0.005 \\
\hline & Turbidity, NTU & +37.4 & 0.035 & +524.3 & 0.012 \\
\hline & Transparency, cm & -33.1 & 0.111 & -8.9 & 0.067 \\
\hline \multirow{11}{*}{ Ex situ } & $\mathrm{Chl} a, \mathrm{mg} / \mathrm{m}^{3}$ & +0.2 & 0.425 & +2.1 & 0.129 \\
\hline & $\mathrm{TSS}, \mathrm{mg} / \mathrm{L}$ & +20.9 & 0.169 & +625.0 & 0.030 \\
\hline & $\mathrm{BOD}_{5}, \mathrm{mg} / \mathrm{L}$ & +0.1 & 0.838 & +0.5 & 0.407 \\
\hline & $\mathrm{COD}, \mathrm{mg} / \mathrm{L}$ & +1.6 & 0.923 & +22.9 & 0.232 \\
\hline & $\mathrm{TS}, \mathrm{mg} / \mathrm{L}$ & +0.05 & 0.439 & +0.75 & 0.016 \\
\hline & $\mathrm{H}_{2} \mathrm{~S}, \mathrm{mg} / \mathrm{L}$ & +0.02 & 0.321 & +0.57 & 0.022 \\
\hline & TAN, mg/L & +0.06 & 0.621 & +0.00 & 0.672 \\
\hline & $\mathrm{NO}_{2}^{-}-\mathrm{N}, \mathrm{mg} / \mathrm{L}$ & +0.000 & 1.000 & +0.005 & 0.039 \\
\hline & $\mathrm{NO}_{3}^{-}-\mathrm{N}, \mathrm{mg} / \mathrm{L}$ & -0.005 & 0.683 & -0.032 & 0.063 \\
\hline & Org-N, mg/L & +0.13 & 0.178 & +0.01 & 0.899 \\
\hline & $\mathrm{TP}, \mathrm{mg} / \mathrm{L}$ & -0.78 & 0.101 & -0.04 & 0.861 \\
\hline
\end{tabular}

These relationships indicate that after the rainfall event, the DOsat and DO contents in the river were mainly regulated by the decomposition of organic matter originating from the increased runoff after rain.

The turbidity values ranged from $3.1 \mathrm{NTU}$ to 88.8 NTU and from 6.0 NTU to 1091.5 NTU during the first and second trips, respectively. Turbidity was significantly higher ( $p$ value $\leq 0.05)$ at the upper part of the main river, whereas the lowest turbidity values were observed in tributaries during both trips (Fig. 2). Significantly higher turbidity values were found after rain $(p$ value $\leq 0.05)$ and in the main river ( $p$ value $\leq 0.05$ ). The turbidity value after rain in the present study was found to be considerably lower than the turbidity value in the Gaoping River, Taiwan after a typhoon-induced extreme rainfall event that reached 57000 NTU. The Batang Baram and its tributaries were significantly less transparent after rain $(p$ value $\leq 0.05)$ due to the high turbidity, where the transparency value in the river decreased from $40.9 \mathrm{~cm}$ to $9.7 \mathrm{~cm}$. No significant difference in transparency between the main river and tributaries before and after rain ( $p$ value $>0.05$ ) was observed. The turbidity value in the river was mostly caused by the high suspended solids as proven by the significant positive correlation between turbidity and TSS ( $p$ value $\leq 0.05$ ). In both sampling trips, the highest TSS occurred at the upper part of the main river where before rain it was observed at station $3(83.8 \mathrm{mg} / \mathrm{L})$ while after rain it was at station $1(1363.3 \mathrm{mg} / \mathrm{L})$ (Fig. 3). In addition, after rain TSS in the main river was in a decreasing trend, indicating loading from the main river upstream. The lowest TSS values were found at station $7(5.0 \mathrm{mg} / \mathrm{L})$ and station $4(31.1 \mathrm{mg} / \mathrm{L})$, which were located in tributaries during the first and second trips, respectively. TSS value at the Batang Baram increased substantially after rain but was not statistically significant ( $p$ value $=0.057$ ) However, TSS value in the main river was significantly higher $(p$ value $\leq 0.05)$ than in tributaries after rain.

The results show that the rainfall was transporting large amounts of sediment into the river. Similarly, the highest suspended sediment concentration was reported during the first storm event after an extended drought period in the Enxoé temporary rive in southern Portugal [24]. In general, stations $2,3,5$, and 6 , which were subjected to logging activities, showed high turbidity and substantial suspended solids during both trips, indicating that the logging activities had increased the sedimentation of the area [25]. Similarly, the Baleh River in Sarawak, which was subjected to logging activities, also showed elevated turbidity and TSS values, particularly after rain [26]. In the present study, comparatively, stations that were located near to the longhouse tend to show lower turbidity and suspended solids. However, the highest turbidity and 


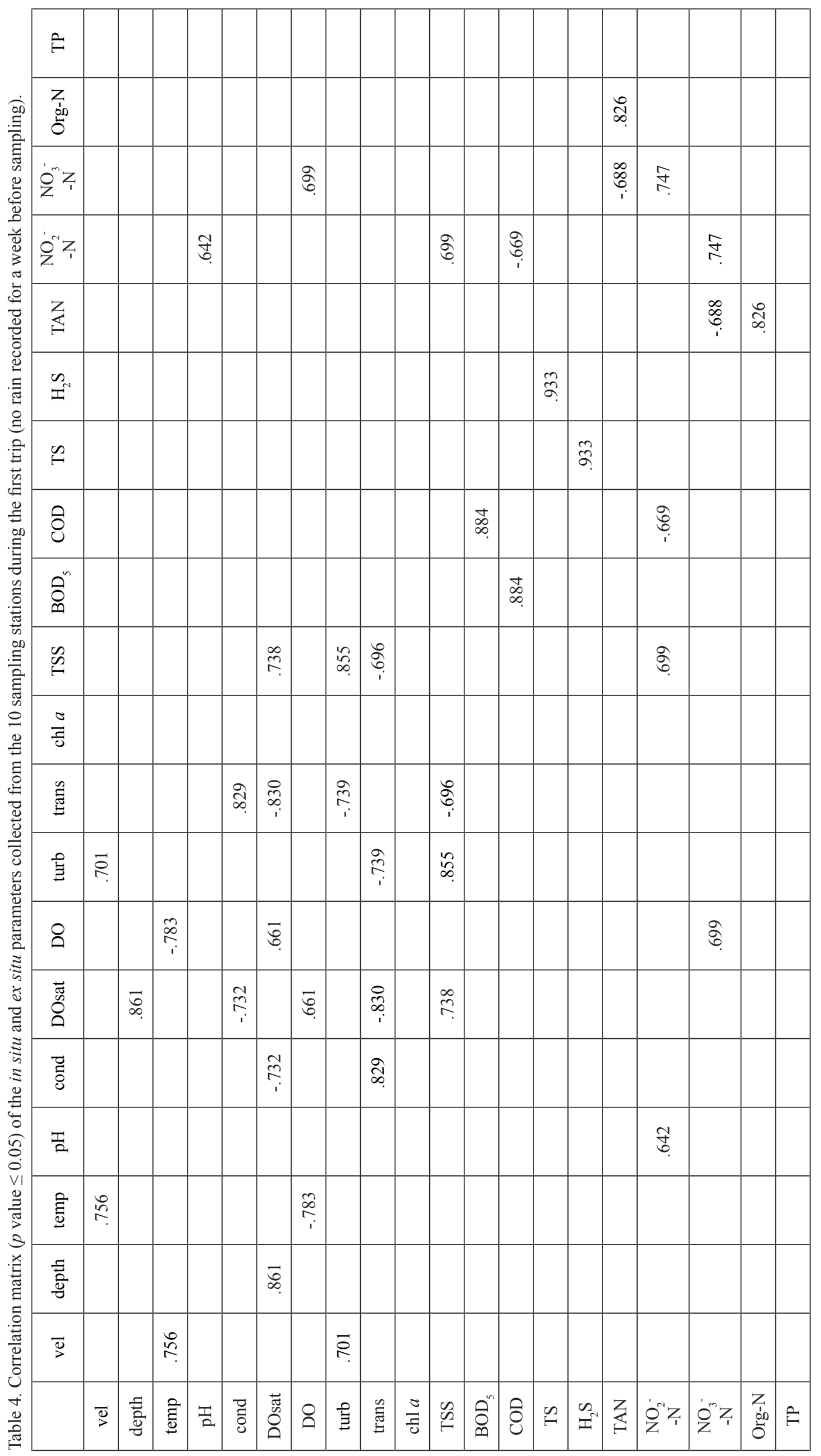




\begin{tabular}{|c|c|c|c|c|c|c|c|c|c|c|c|c|c|c|c|c|c|c|c|c|c|c|}
\hline & & & & & & & & & & & & & & & & & & & & & & \\
\hline & & & & ర్ర & & & & & & & & 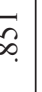 & & & & & & & & & & \\
\hline & & & & & & & & & & & & & & & & & & & & & & \\
\hline & & אִ & & & $\stackrel{\Omega}{r}$ & & 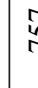 & & & & & & $\tilde{\infty}$ & & & š & & & & & & \\
\hline & & $\frac{6}{6}$ & & & ? & & $\S$ & & ? & & & & $\begin{array}{c}\infty \\
\infty \\
\infty\end{array}$ & & & & ธี & & & & & \\
\hline & & & బ్ & & & & 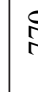 & & 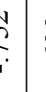 & & ? & & క్ర & & & & & & & & & \\
\hline & & & \& & & & & 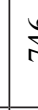 & & & & & & $\begin{array}{l}\text { lo } \\
.\end{array}$ & & & & & & & & & \\
\hline & & ô. & $\tilde{b}$ & & & & $\breve{z}$ & & : & & & & & $\begin{array}{l}\stackrel{n}{n} \\
?\end{array}$ & है & $\begin{array}{c}\infty \\
\infty \\
\infty\end{array}$ & 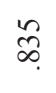 & & & & & \\
\hline & & & & & & & & & & & & & & & & 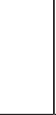 & & & $\vec{\varpi}$ & & & \\
\hline & & & & $\underset{\infty}{\infty}$ & & & & & & & & & & & 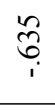 & & & & & & & \\
\hline & & 承. & & & & & $\check{c}$ & & & & & & $\widehat{s}$ & & ợ & gh & హె & & & & & \\
\hline & & $\hat{c}$ & & & & & $\check{c}$ & & & & e & & $\begin{array}{l}\infty \\
\infty \\
\infty \\
\infty\end{array}$ & & م̂ & $\stackrel{R}{?}$ & $\stackrel{\infty}{?}$ & & & 苞 & & \\
\hline & & : & & & & & & & & & & & $\tilde{n}$ & $\frac{0}{+}$ & $\underset{i}{?}$ & $\underset{\infty}{~}$ & in & & & & & \\
\hline & & & & & & & & & & & & & & & & & & & & & & \\
\hline & & & & & & & & & & & & & & & & in & $\hat{\Omega}$ & & & & & \\
\hline & & & & & & & & & & & है & & & & & & & & త్రి & : & & \\
\hline & & & & & & & & & & & & & $\hat{\widehat{b}}$ & 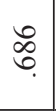 & $\begin{array}{l}\mathscr{0} \\
0 \\
0\end{array}$ & & & & & & & \\
\hline & & & & & & & $\$$ & & & ? & & & $\begin{array}{l}\infty \\
\stackrel{\alpha}{o}\end{array}$ & & & $\frac{m}{\sigma}$ & $\begin{array}{c}\tilde{\infty} \\
\infty\end{array}$ & & & & & \\
\hline & & $\bar{p}$ & $\bar{z}$ & శ్ & I & 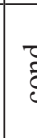 & 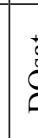 & & & 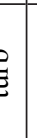 & 彭 & $\frac{\pi}{0}$ & $\begin{array}{l}2 \\
\vdots \\
n\end{array}$ & రి & o & 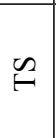 & $\stackrel{n}{x}$ & $z$ & $\mid \begin{array}{l}z_{1} \\
\delta^{\prime}\end{array}$ & $\mid \begin{array}{l}z_{1} \\
\vdots \\
\delta^{\prime}\end{array}$ & 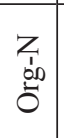 & 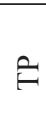 \\
\hline
\end{tabular}


suspended solids were observed at station 1 after rain, which was most probably due to the resuspension of deposited sediment under high flow rates as the highest mean velocity after the rainfall event was recorded there. This is further supported by the significant correlation between turbidity, TSS, and mean velocity ( $p$ value $\leq 0.05)$.

Significantly higher ( $p$ value $\leq 0.05)$ chl $a$ concentration was observed in the Batang Baram and its tributaries after rain, where there was an increase from $0.5 \mathrm{mg} / \mathrm{m}^{3}$ to $2.3 \mathrm{mg} / \mathrm{m}^{3}$. The highest and the lowest chl $a$ concentrations were located at station $1\left(1.6 \mathrm{mg} / \mathrm{m}^{3}\right)$ and station $6\left(0.2 \mathrm{mg} / \mathrm{m}^{3}\right)$ before rain, and station $8\left(7.7 \mathrm{mg} / \mathrm{m}^{3}\right)$ and station $7\left(0.5 \mathrm{mg} / \mathrm{m}^{3}\right)$ after rain, respectively (Fig. 3). The highest chl $a$ concentration was found near the longhouses and in the main river, whereas the lowest concentration of chl $a$ was observed in the tributary. However, there was no significant difference ( $p$ value $>0.05$ ) in chl $a$ concentration between the main river and tributaries. The higher chl $a$ concentration near the longhouses was most probably due to the nutrient availability from domestic wastewater, which favors their growth [27-29]. This is further evidenced by the significant correlation between chl $a$ and $\mathrm{NO}_{2}^{-}-\mathrm{N}$ concentrations in the river after rain $(p$ value $\leq 0.05)$.

$\mathrm{BOD}_{5}$ and COD concentrations did not differ significantly before and after rain (Table $2, p$ value $>0.05$ ) or between the main river and tributaries (Table 3, $p$ value $>0.05$ ). However, the rainfall event might have an influence on the distribution patterns of the $\mathrm{BOD}_{5}$
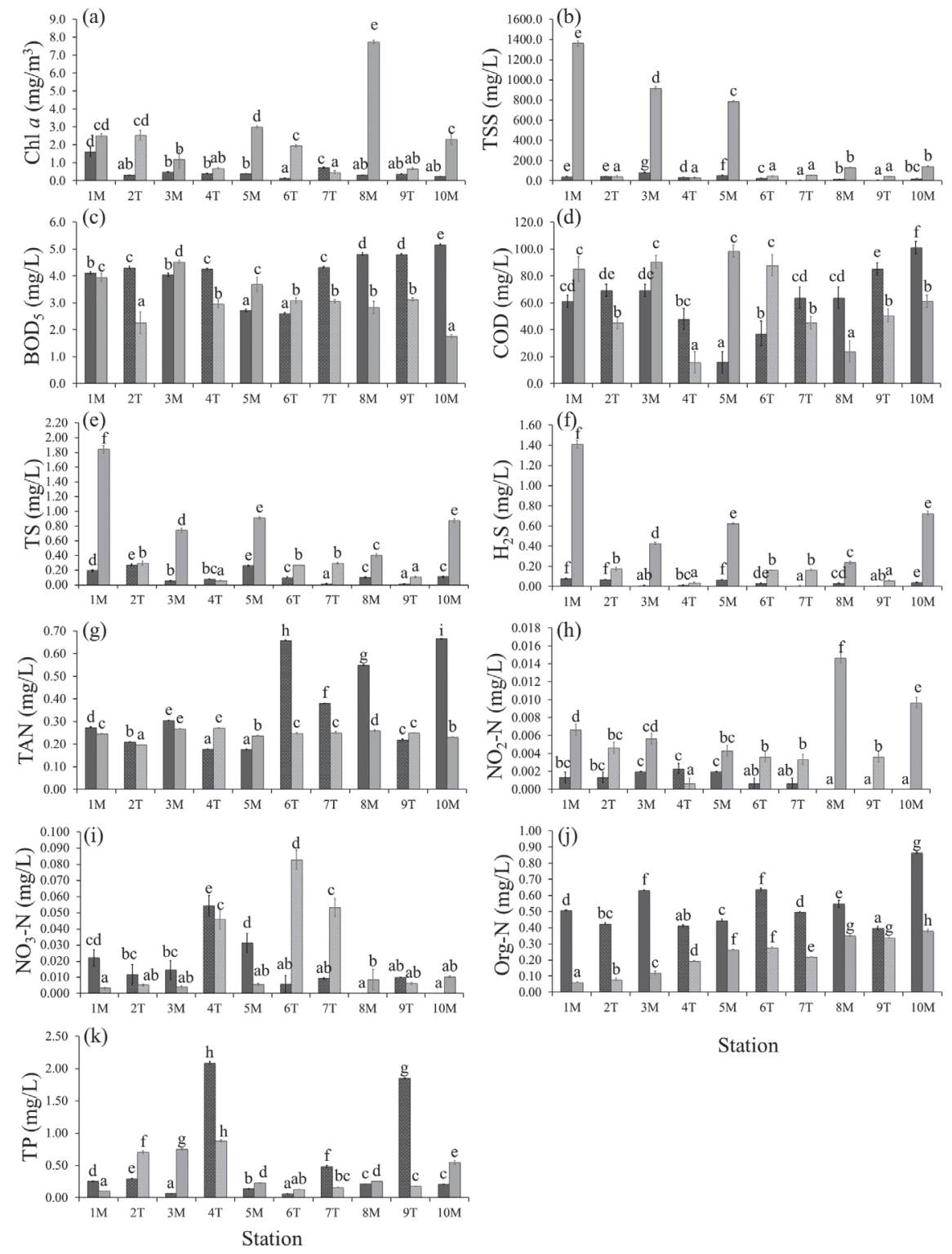

Station

Legend $\square$ Trip $1 \quad \square$ Trip 2

Fig. 3. Ex situ water quality of a) chl $a$, b) TSS, c), $\mathrm{BOD}_{5}$, d) COD, e) TS, f) $\mathrm{H}_{2} \mathrm{~S}, \mathrm{~g}$ ) TAN, h) $\mathrm{NO}_{2}^{-}-\mathrm{N}^{-}$, i) $\mathrm{NO}_{3}^{-}-\mathrm{N}$, j) Org-N, and k) TP collected at the ten sampling stations located along the Batang Baram during two different trips (different letters indicate significant difference at $p$ value $\leq 0.05$ during each trip). 
and COD concentrations along the river. Both $\mathrm{BOD}_{5}$ and COD concentrations were found to be significantly lower ( $p$ value $\leq 0.05)$ at the middle section of the river (stations 5 and 6) than the upper and lower parts of the river during the first trip (Fig. 3). After the rainfall event, significantly higher $(p$ value $\leq 0.05) \mathrm{BOD}_{5}$ concentrations were found upstream and it gradually decreased moving downstream, whereas the $\mathrm{BOD}_{5}$ concentrations remained relatively constant in the tributaries $(2.3-3.1 \mathrm{mg} / \mathrm{L})$. The COD concentrations were found significantly higher ( $p$ value $\leq 0.05$ ) at the upper part of the main river (stations 1,3 , and 5) and at one of the tributaries (station 6). The higher concentrations of $\mathrm{BOD}_{5}$ and $\mathrm{COD}$ at the upstream area indicated that high organic matter was derived from anthropogenic sources in the upstream. Organic matter in the present study area was most likely attributed to the domestic discharge and runoff as those stations were located near longhouses and logging activities. The decrease of $\mathrm{BOD}_{5}$ concentration along the river indicates the fast decomposition of the biodegradable organic matter in the river. However, the COD concentration shows that non-biodegradable organic matter remained high in the main river and shows signs of decrease after station 7. The $\mathrm{BOD}_{5}$ and COD concentrations did not correlate significantly with other in situ parameters before rain ( $p$ value $>0.05)$. After the rainfall event, the $\mathrm{BOD}_{5}$ concentration was significantly and positively correlated with mean depth and TSS ( $p$ value $\leq 0.05$ ), whereas the COD concentration was significantly and positively correlated with mean depth, turbidity, and TSS ( $p$ value $\leq 0.05$ ) - indicating that the organic matter which was attached to the suspended solids increased due to the increased surface runoff after rain [13]. The decomposition of organic matter and respiration of bacteria reduced the dissolved oxygen content in the river as indicated by the significant negative correlation between $\mathrm{BOD}_{5}$ concentration and DOsat ( $p$ value $\leq 0.05$ ), and between COD concentration and DOsat and DO ( $p$ value $\leq 0.05$ ).

The TS and $\mathrm{H}_{2} \mathrm{~S}$ concentrations in the Batang Baram increased significantly ( $p$ value $\leq 0.05$ ) after the rainfall event, particularly in the main river as shown by the significantly higher ( $p$ value $\leq 0.05$ ) concentrations in the main river after rain. When no rain was recorded during a week before sampling, the TS was significantly higher $(p$ value $\leq 0.05$ ) at stations 1,2 , and 5 $(\approx 0.24 \mathrm{mg} / \mathrm{L})$, indicating that the TS originated from the adjacent longhouse and logging activities. After the rainfall event, significantly higher TS $(1.84 \mathrm{mg} / \mathrm{L})$ and $\mathrm{H}_{2} \mathrm{~S}$ $(1.41 \mathrm{mg} / \mathrm{L})$ concentrations were observed at station 1 ( $p$ value $\leq 0.05$ ). The four other stations located along the main river also contained significantly higher TS $(\approx 0.73 \mathrm{mg} / \mathrm{L})$ and $\mathrm{H}_{2} \mathrm{~S}(\approx 0.50 \mathrm{mg} / \mathrm{L})$ concentrations ( $p$ value $\leq 0.05$ ). The high volume of surface runoff after rain increased the TS and $\mathrm{H}_{2} \mathrm{~S}$ concentrations in the river as indicated by their significant correlation ( $p$ value $\leq 0.05)$ with mean velocity after rain. Similar to $\mathrm{BOD}_{5}$ and $\mathrm{COD}$, TS and $\mathrm{H}_{2} \mathrm{~S}$ concentrations were also significantly and positively correlated with turbidity and
TSS ( $p$ value $\leq 0.05$ ), as most of the pollutants are attached to the particles, and negatively correlated with DOsat and DO ( $p$ value $\leq 0.05$ ) as the decomposition of organic matter consumes oxygen in the river.

The TAN concentrations ranged from $0.18 \mathrm{mg} / \mathrm{L}$ to $0.67 \mathrm{mg} / \mathrm{L}$ and from $0.20 \mathrm{mg} / \mathrm{L}$ to $0.27 \mathrm{mg} / \mathrm{L}$, when no rain was recorded for a week before sampling and it rained one night before sampling, respectively. No significant difference in TAN concentration ( $p$ value $>0.05$ ) was observed before rain and after rain, and between the main river and tributaries; but TAN concentrations were significantly higher ( $p$ value $\leq 0.05$ ) at stations $6,7,8$, and 10 when there was no rain, and became relatively consistent along the river after rain. The extremely high concentrations at those stations suggested that the longhouses and logging activities most likely contributed substantial TAN in the area but was diluted by the rain. Ammonium was found to be negatively correlated with rainfall in the Burnt Mill Creek and Smith Creek, USA [13]. The authors hypothesized that rainfall creates better mixing and oxic conditions that enhance nitrification, and cools the water and reduces $\mathrm{pH}$, which may reduce the formation and accumulation of ammonium.

The $\mathrm{NO}_{2}^{-}-\mathrm{N}$ exhibited a similar trend with $\mathrm{TS}$ and $\mathrm{H}_{2} \mathrm{~S}$, where $\mathrm{NO}_{2}^{-}-\mathrm{N}$ concentration increased significantly ( $p$ value $\leq 0.05$ ) after rain particularly in the main river where the $\mathrm{NO}_{2}^{-}-\mathrm{N}$ concentration in the main river was significantly higher ( $p$ value $\leq 0.05$ ) than tributaries. When there was no rain recorded for a week before sampling, the $\mathrm{NO}_{2}-\mathrm{N}$ concentrations were found to be decreasing along the main river. In contrast to TS and $\mathrm{H}_{2} \mathrm{~S}$, where the highest concentration was observed at station 1 , significantly higher concentrations of $\mathrm{NO}_{2}^{-}-\mathrm{N}(p$ value $\leq 0.05)$ were observed at stations 8 and 10 after the rainfall event. This could be due to the abundance of ammoniumoxidizing bacteria that oxidized ammonium to nitrite in the nitrification process, which leads to the higher $\mathrm{NO}_{2}-\mathrm{N}$ concentration at stations 8 and 10 , whereas

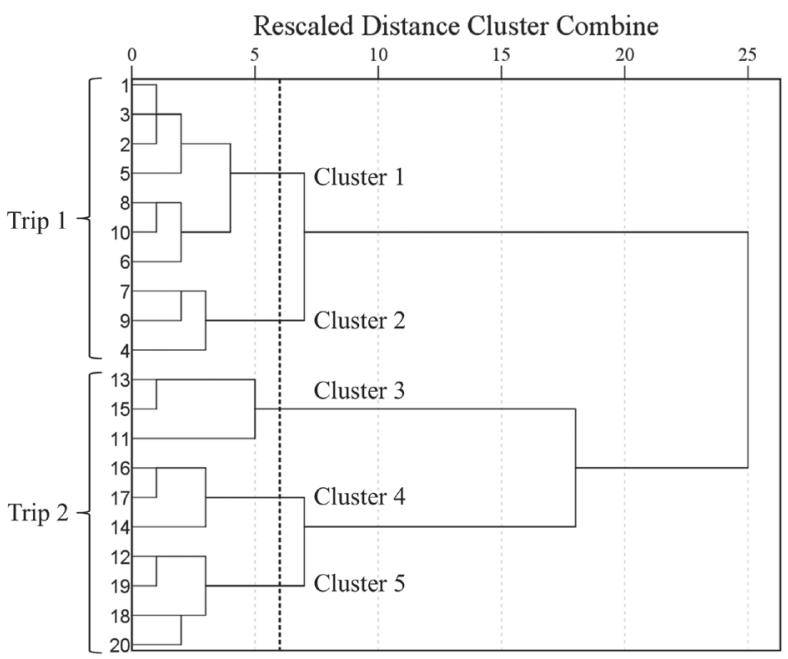

Fig. 4. Clustering of the ten sampling stations during the two sampling trips. 
anaerobic bacteria that use sulfate instead of oxygen produces toxic hydrogen sulphide during the decomposition of organic matter at station 1 .

The $\mathrm{NO}_{3}^{-}-\mathrm{N}$ concentration exhibited different trends of distribution where higher $\mathrm{NO}_{3}^{-} \mathrm{N}$ concentration was observed in the middle of the river studied. There was no significant difference in $\mathrm{NO}_{3}^{-}-\mathrm{N}$ concentrations ( $p$ value $>0.05$ ) before and after rain, and between main river and tributaries. Significantly higher concentrations of $\mathrm{NO}_{3}{ }^{-}-\mathrm{N}$ were observed at stations 4 and 5 before rain ( $p$ value $\leq 0.05$ ), whereas significantly higher concentrations of $\mathrm{NO}_{3}^{-}-\mathrm{N}$ were observed at stations 4,6 , and 7 after the rainfall event ( $p$ value $\leq 0.05$ ). The high concentration at those stations could be due to the domestic discharge and surface runoff that contained substantial $\mathrm{NO}_{3}-\mathrm{N}$ concentration. The $\mathrm{NO}_{3}^{-}-\mathrm{N}$ concentration was significantly and positively correlated with DO and $\mathrm{NO}_{2}^{-}-\mathrm{N}$ concentration but negatively correlated with TAN concentration during the first trip ( $p$ value $\leq 0.05$ ); and significantly and positively correlated with DO but negatively correlated with temperature during the second trip ( $p$ value $\leq 0.05)$. These relationships indicate that the high DO content in the river favors the nitrification process that converts the nitrogen into the $\mathrm{NO}_{3}{ }^{-}-\mathrm{N}$ form.

The highest concentration of Org-N was observed at station 10 during both trips. The Org-N concentrations in the river ranged from $0.40 \mathrm{mg} / \mathrm{L}$ to $0.86 \mathrm{mg} / \mathrm{L}$ when there was no rain recorded for a week before the first trip, whereas a noticeable increasing trend was observed along the river after rain, ranging from $0.06 \mathrm{mg} / \mathrm{L}$ to $0.38 \mathrm{mg} / \mathrm{L}$. In contrast to $\mathrm{NO}_{2}^{-}-\mathrm{N}$ concentration, which increased significantly ( $p$ value $\leq 0.05$ ) after rain, Org-N concentration was found to decrease significantly ( $p$ value $\leq 0.05)$ after the rainfall event, indicating the rapid decomposition of organic matter and conversion into inorganic nitrogen form after rain.

There was no significant difference in TP ( $p$ value $>0.05$ ) before and after rain (Table 2), or between the main river and tributaries (Table 3). Significantly higher TP concentrations were observed at stations 4 and $9(\approx 1.97 \mathrm{mg} / \mathrm{L})$ before rain $(p$ value $\leq 0.05)$, and significantly higher TP concentrations were found at stations 2,3 , and $4(\approx 0.78 \mathrm{mg} / \mathrm{L})$ after rain $(p$ value $\leq 0.05)$, as illustrated in Fig. 3. The highest concentration of TP was observed at station 4 during both trips. Stations 4 and 9

Table 6. Classification of water quality of the 10 sampling stations according to WQI, when no rain was recorded for a week before sampling (first trip) and it rained one night before sampling (second trip).

\begin{tabular}{|c|c|c|c|c|c|c|c|c|c|c|}
\hline \multirow{2}{*}{ Trip } & \multirow{2}{*}{ Type } & \multirow{2}{*}{ Station } & \multicolumn{7}{|c|}{ CLASS } & \multirow{2}{*}{ Status } \\
\hline & & & $\mathrm{AN}$ & $\mathrm{BOD}_{5}$ & COD & DO & $\mathrm{pH}$ & TSS & WQI & \\
\hline \multirow{10}{*}{ First } & \multirow{5}{*}{ Main } & 1 & II & III & IV & II & $\mathrm{I}$ & II & III & Slightly polluted \\
\hline & & 3 & III & III & IV & II & I & III & III & Slightly polluted \\
\hline & & 5 & II & II & II & II & I & III & II & Clean \\
\hline & & 8 & III & III & IV & II & I & I & III & Slightly polluted \\
\hline & & 10 & III & III & V & II & I & I & III & Slightly polluted \\
\hline & \multirow{5}{*}{ Tributary } & 2 & II & III & IV & II & I & II & III & Slightly polluted \\
\hline & & 4 & II & III & III & II & I & II & II & Slightly polluted \\
\hline & & 6 & III & II & III & II & I & II & II & Slightly polluted \\
\hline & & 7 & III & III & IV & II & I & I & II & Slightly polluted \\
\hline & & 9 & II & III & IV & II & I & I & III & Slightly polluted \\
\hline \multirow{10}{*}{ Second } & \multirow{5}{*}{ Main } & 1 & II & III & IV & II & II & V & III & Slightly polluted \\
\hline & & 3 & II & III & IV & II & II & V & III & Slightly polluted \\
\hline & & 5 & II & III & IV & II & II & V & III & Slightly polluted \\
\hline & & 8 & II & II & II & I & II & III & II & Slightly polluted \\
\hline & & 10 & II & II & IV & I & II & III & III & Slightly polluted \\
\hline & \multirow{5}{*}{ Tributary } & 2 & II & II & III & I & II & II & II & Clean \\
\hline & & 4 & II & II & II & I & II & II & II & Clean \\
\hline & & 6 & II & III & IV & I & II & II & II & Slightly polluted \\
\hline & & 7 & II & III & III & I & II & III & II & Clean \\
\hline & & 9 & II & III & IV & I & II & II & II & Clean \\
\hline
\end{tabular}


were located near the logging camp and longhouses, which most likely contributed substantial TP into the river, whereas stations 2 and 3 were subjected to logging activities. The Batang Baleh in Sarawak that was subjected to logging activities also showed significantly higher TP concentration after rain [26].

\section{Cluster Analysis (CA)}

Cluster analysis (CA) was applied to detect similarities among the sampling stations using the in situ and ex situ parameters of the 10 stations collected during two different trips. The dendrogram shows that the 10 sampling stations can be grouped into five clusters (Fig. 4). Clusters 1 and 2 consist of stations studied during the first trip, whereas clusters 3, 4, and 5 consist of stations that were studied during the second trip. This clustering demonstrates that the rainfall event has a great influence on the water quality of the Batang Baram. Before the rain, most of the stations at Batang Baram and its tributaries shared similar characteristics and are grouped together as cluster 1 except for stations 4, 7, and 9, which are the tributaries of Batang Baram. After the rain, the Batang Baram can be differentiated by the upper part of the main river (cluster 3), the tributary (cluster 4), and the downstream of the river, which also included a tributary where station 2 is located (cluster 5). This clustering shows that the main river and tributaries of the Batang Baram shared no similarity after the rain. Besides, the upstream and downstream of the Batang Baram showed different characteristics after rain as shown by clusters 3 and 5 . However, one of the tributaries, represented by station 2 , shared similar characteristics with the downstream river and is grouped together as cluster 5 .

\section{Water Quality Index (WQI)}

When no rain was recorded for a week before the sampling, the Batang Baram and its tributaries were classified as Class II or III according to the water quality index (WQI; Table 6). Four out of five stations located in the main river of the Batang Baram and two out of five stations located in the tributary were classified as Class III. Almost all stations were categorized as 'slightly polluted' except station 5, which was categorized as 'clean.' Among the six parameters, $\mathrm{pH}$ and DO were classified as Class $\mathrm{I}$ and II, respectively, whereas the $\mathrm{AN}$ and $\mathrm{BOD}_{5}$ were classified as Class II and/or III. The worst classification of the parameter was COD, which was mostly classified as Class IV.

The WQI of the main river of the Batang Baram remained unchanged after rain, where four out of five stations were classified as Class III. However, all stations located in the main river were categorized as 'slightly polluted' after rain. The water quality of tributaries improved after rain where all of the stations were classified as Class II and categorized as 'clean,' except station 6, which was categorized as 'slightly polluted.' The improved parameters included DO and AN, whereas
$\mathrm{pH}$ and TSS deteriorated after rain. After the rainfall event, the worst classification of the parameter in the river was TSS, where there were three stations classified as Class V. The deterioration in TSS was also reported in the Batang Baleh, where the TSS changed from Class I to Class III and/or IV after rain [26].

\section{Conclusions}

The present study shows that a rainfall event has a major impact on the physicochemical characteristics of the Batang Baram and its tributaries. The rainfall event increased the mean velocity of the river. Subsequently, the rainfall runoff and the fast flowing river adversely impacted the water quality in the river, particularly $\mathrm{pH}$, transparency, turbidity, TSS, TS, $\mathrm{H}_{2} \mathrm{~S}, \mathrm{chl} a$, and $\mathrm{NO}_{2}^{-}-\mathrm{N}$. However, the DO content showed an improvement in the river, and Org- $\mathrm{N}$ concentration decreased significantly ( $p$ value $\leq 0.05$ ) after rain. The WQI of the river was mostly classified as Class II and/or III and categorized as 'slightly polluted,' particularly due to the high COD concentration. After the rainfall event, the WQI of the tributaries showed improvement due to the high DO content, although the TSS deteriorated after rain.

\section{Acknowledgements}

The authors appreciate the financial support provided by the Sarawak Energy Berhad through Grant No. $\mathrm{GL}(\mathrm{F} 07) / \mathrm{SEB} / 3 \mathrm{C} / 2013(22)$, and the facilities provided by Universiti Malaysia Sarawak.

\section{References}

1. WANG D., HAGEN S.C., ALIZAD K. Climate change impact and uncertainty analysis of extreme rainfall events in the Apalachicola River basin, Florida. J. Hydrol. 480, 125, 2013.

2. LOO Y.Y., BILLA L., SINGH A. Effect of climate change on seasonal monsoon in Asia and its impact on the variability of monsoon rainfall in Southeast Asia. Geosci. Frontiers. 6 (6), 817, 2015.

3. PARK J.H., INAM E., ABDULLAH M.H., AGUSTIYANI D., DUAN L., HOANG T.T., KIM K.W., KIM S.D., NGUYEN M.H., PEKTHONG T., SAO V., SARJIYA A., SAVATHVONG S., STHIANNOPKAO S., KEITH SYERS J., WIROJANAGUD W. Implications of rainfall variability for seasonality and climate-induced risks concerning surface water quality in East Asia. J. Hydrol. 400 (3-4), 323, 2011.

4. ZHOU Z.Z., HUANG T.L., MA W.X., LI Y., ZENG K. Impacts of water quality variation and rainfall runoff on Jinpen Reservoir, in Northwest China. Water Sci. Eng. 8 (4), 301, 2015.

5. LEE C., LEE Y., CHIANG H. Abrupt state change of river water quality (turbidity): Effect of extreme rainfalls and typhoons. Sci. Total Environ. 557-558, 91, 2016.

6. CORBARI C., LASSINI F., MANCINI M. Effect of intense short rainfall events on coastal water quality parameters from remote sensing data. Cont. Shelf. Res. 123, 18, 2016. 
7. ZHANG Y., SHI K., ZHOU Y., LIU X., QIN B. Monitoring the river plume induced by heavy rainfall events in large, shallow, Lake Taihu using MODIS 250 m imagery. Remote Sens. Environ. 173, 109, 2016.

8. CAMARGO J.A., ALONSO A. Ecological and toxicological effects of inorganic nitrogen pollution in aquatic ecosystems: A global assessment. Environ. Int. 32 (6), 831, 2006.

9. SMITH V.H., TILMAN G.D., NEKOLA J.C. Eutrophication: Impacts of excess nutrient inputs on freshwater, marine, and terrestrial ecosystems. Environ. Pollut. 100 (1-3), 179, 1999.

10. ISLAM M.S., TANAKA M. Impacts of pollution on coastal and marine ecosystems including coastal and marine fisheries and approach for management: A review and synthesis. Mar. Pollut. Bull. 48, 624, 2004.

11. SCHNEIDER S.C., CARA M., ERIKSEN T.E., BUDZAKOSKA GORESKA B., IMERI A., KUPE L., LOKOSKA T., PATCEVA S., TRAJANOVSKA S., TRAJANOVSKI S., TALEVSKA M., VELJANOSKA SARAFILOSKA E. Eutrophication impacts littoral biota in Lake Ohrid while water phosphorus concentrations are low. Limnologica, 44, 90, 2014.

12. MATHAI J., HON J., JUAT N., PETER A., GUMAL M. Small carnivores in a logging concession in the Upper Baram, Sarawak, Borneo. Small Carniv. Conserv. 42, 1, 2010.

13. MALLIN M.A., JOHNSON V.L., ENSIGN S.H. Comparative impacts of stormwater runoff on water quality of an urban, a suburban, and a rural stream. Environ. Monit. Assess. 159 (1-4), 475, 2009.

14. XIA Y., TI C., SHE D., YAN X. Linking river nutrient concentrations to land use and rainfall in a paddy agricultureurban area gradient watershed in southeast China. Sci. Total Environ. 566-567, 1094, 2016.

15. KIM G., CHUNG S., LEE C. Water quality of runoff from agricultural-forestry watersheds in the Geum River Basin, Korea. Environ. Monit. Assess. 134 (1-3), 441, 2007.

16. CHAPRA S.C. Surface Water-Quality Modeling; McGrawHill Inc: New York, USA, 844, 1997.

17. JENKINS D., CONNORS J.J., GREENBERG A.E. Standard Methods for the Examination of Water and Wastewater, $21^{\text {st }}$ edition; American Public Health Association: Washington, DC, USA, 1200, 2005.

18. HACH. Hach Water Analysis Handbook; Hach Company: Loveland, Colo, USA, 2015.

19. DEPARTMENT OF ENVIRONMENT. Malaysia Environmental Quality Report 2014; Department of Environment: Kuala Lumpur, Malaysia, 162, 2015.
20. PAAIJMANS K.P., TAKKEN W., GITHEKO A.K., JACOBS A.F.G. The effect of water turbidity on the nearsurface water temperature of larval habitats of the malaria mosquito Anopheles gambiae. Int. J. Biometeorol. 52 (8), 747, 2008.

21. LING T.Y., ABDUL-GHANI R., HAMDAN N., LEE N. Impacts of residential areas and aquaculture on the sediment quality of Semariang Batu River in Sarawak, Malaysia. Int. J. Chem. Environ. Eng. 3 (2), 86, 2012.

22. JUAHIR H., ZAIN S.M., YUSOFF M.K., HANIDZA T.I.T., ARMI A.S.M., TORIMAN M.E., MOKHTAR M. Spatial water quality assessment of Langat River Basin (Malaysia) using environmetric techniques. Environ. Monit. Assess. 173, 625, 2011.

23. OUYANG T., ZHU Z., KUANG Y. River water quality and pollution sources in the Pearl River Delta, China. J. Environ. Monit. 7 (7), 664, 2005.

24. RAMOS T.B., GONÇALVES M.C., BRANCO M.A., BRITO D., RODRIGUES S., SÁNCHEZ-PÉREZ J.M., SAUVAGE S., PRAZERES Â., MARTINS J.C., FERNANDES M.L., PIRES F.P. Sediment and nutrient dynamics during storm events in the Enxoé temporary river, southern Portugal. Catena. 127, 177, 2015.

25. FULTON S., WEST B. Forestry impacts on water quality. In Southern Forest Resource Assessment; Wear, Greis, Eds., U.S. Department of Agriculture: Asheville, NC, USA, 635, 2002.

26. LING T.Y., SOO C.L., SIVALINGAM J.R., NYANTI L., SIM S.F., GRINANG J. Assessment of the water and sediment quality of tropical forest streams in upper reaches of Baleh River, Sarawak, Malaysia, subjected to logging activities. J. Chem. 2016, 1, 2016.

27. LIANG Y., BEARDALL J., HERAUD P. Effects of nitrogen source and UV radiation on the growth, chlorophyll fluorescence and fatty acid composition of Phaeodactylum tricornutum and Chaetoceros muelleri (Bacillariophyceae). J. Photochem. Photobiol. B. 82, (3), 161, 2006.

28. LLEBOT C., SPITZ Y. H., SOLÉ J., ESTRADA M. The role of inorganic nutrients and dissolved organic phosphorus in the phytoplankton dynamics of a Mediterranean bay. J. Mar. Syst. 83 (3-4), 192, 2010.

29. XU J., HO A.Y.T., YIN K., YUAN X., ANDERSON D.M., LEE J.H.W., HARRISON P.J. Temporal and spatial variations in nutrient stoichiometry and regulation of phytoplankton biomass in Hong Kong waters: Influence of the Pearl River outflow and sewage inputs. Mar. Pollut. Bull. 57 (6-12), 335, 2008. 